Indonesian Journal of Chemical Research

\title{
Density Functional Theory for QSAR Antioxidant Compound Myristicin Derivatives
}

\author{
Muliadi ${ }^{*}$, Mudzuna Quraisyah Basimin, Ahmad Muchsin Jayali \\ Chemistry Education Department, Khairun University, Jl. Bandara Babullah, Ternate 97728 Indonesia \\ *Corresponding author: muliadi@unkhair.ac.id
}

Received: April 2021

Received in revised: April 2021

Accepted: May 2021

Available online: May 2021

\begin{abstract}
This research was conducted to determine the molecular structure modeling and the quantitative relationship of the activity structure (QSAR) of substituted myristicin derivatives with electron donor groups such as $-\mathrm{C}_{6} \mathrm{H}_{5}(\mathrm{M} 1),-\mathrm{NH}_{2}(\mathrm{M} 2),-\mathrm{Cl}$ (M3), -F (M4), and -H (M5). The results of geometry optimization with the DFT (Density Fractal Theory) method or density functional calculations calculated with the density level of B3LYP/6-31G each obtained the total energy of each compound M1- M5: M1: $175.49 \mathrm{kcal} / \mathrm{mol} \mathrm{M} 2: 132.707 \mathrm{kcal} / \mathrm{mol}, \mathrm{M} 3: 115.701 \mathrm{kcal} / \mathrm{mol}, \mathrm{M} 4: 116.048 \mathrm{kcal} / \mathrm{mol}$, M5: $121.377 \mathrm{kcal} / \mathrm{mol}$. Determining the relationship between descriptors and the antioxidant activity $\left(\mathrm{IC}_{50}\right)$ for basic structure myristicin compounds and five derivatives was carried out using SPSS 21 . The results of the correlation analysis showed that there was a relationship between the descriptors and antioxidant activity. Determining the best QSAR equation model is done by analyzing multiple linear and multilinear regression using IBM SPSS 21. The results of multiple linear regression analysis or multilinear regression obtained for the best QSAR equation model are: $\log \mathrm{P}=-2.600+(0.006)$ IW- (1.558) qC8 - (6.532) EHOMO + (0.014) PSA + (0.133) MD with $\mathrm{n}=6, \mathrm{R}=1.000$, $\mathrm{R}^{2}=0.926, \mathrm{SE}=0$.
\end{abstract}

Keywords: Myristicin, geometry optimization, DFT Method, QSAR Method

\section{INTRODUCTION}

Over time, the human lifestyle has undergone many changes, such as eating habits that preferfast food (Ginting et al., 2017). The fast-food with high heating and burning triggers the formation of free radical compounds. When human consumed this food too much, can cause cancer, stroke, diabetes mellitus, atherosclerosis, cataracts, and coronary heart disease (Rohmatussolihat, 2015).

Within a decade, the results of research on free radicals have been intensively reported to trigger various diseases. Free radicals can oxidize nucleic acids, proteins, fats, and even cell DNA and initiate degenerative diseases (Rifai, Kasmui, \& Hadisaputro, 2014). One of the compounds that are believed and widely consumed to prevent dangerous diseases is a compound that has antioxidant properties. A report from (Hasanan, 2015), claims that the ability of antioxidant compounds to prevent free radicals is $50 \%$ greater than vitamin C (Fadillah, Rahmadani, \& Rijai, 2017).

Compounds that have antioxidant properties can naturally be obtained from plants (Damayanti \& Ervilita, 2017). Several plants produce antioxidants, including rukam fruit extract and kesuma keling seed extract (Fadiyah, Lestari, \& Mahardika, 2020; Souhoka, Hattu, \& Huliselan, 2019). In addition, bay leaves, kenitu leaves and bark, strawberry leaves, katuk leaves, and nutmeg have also been reported as antioxidants (Widyastuti, Kusuma, Nurlaili, \& Sukmawati, 2016). Indonesia is the largest nutmeg producing country globally, with about $70-75 \%$ of the total nutmeg production. One of the largest centers of nutmeg production in Indonesia is North Maluku. Nutmeg is a native Indonesian spice plant that has only been used for food and domestic food industry purposes in the form of jam, syrup, and sweets (Dungir, Katja, \& Kamu, 2012). In addition, all parts of the nutmeg can be processed into nutmeg oil, such as seeds, pulp and mace (Ayunani, Hastuti, Ansory, \& Nilawati, 2018). According to research results from (Wibowo, Febriana, Riasari, \& Auilifa, 2018) and (Ismiyarto, Ngadiwiyana, \& Mustika, 2009). The main compound contained in the nutmeg plant is myristicin. Myristicin compounds also have antioxidant properties. Isnaeni et al., (2016) studied 13 analogue compounds of chalcone using steric, hydrophobic, and electronic descriptors computationally calculated using the DFT method, using the Gaussian 09 MarvinBeans-6.0.0 programs (Isnaeni et al., 2016). The results showed that Kalkon compound can increase antioxidant activity. 
The QSAR (Quantitative Structure-Activity Relationship) method has been widely used to design new drugs and computationally study the relationship between the activity and structure (Tahir, Wijaya, Purwono, \& Widianingsih, 2010). Using the QSAR method begins with structural modeling or geometry optimization using the GaussView 6,016 program package to obtain electronic descriptors and the Marvin Sketch 64 program package to obtain hydrophobic and steric descriptors. This biological activity can be predicted through computational computation of molecular descriptors. The QSAR method focuses on correlating activities experimentally with descriptors computationally. Kilo, Aman, Sabihi, \& Kilo, (2019) reported using the QSAR method to determine the potency of pyrazoline as an anti-amoeba. The DFT (Density Finctional Theory) method has proven to be very good for the optimization of molecular structures because DFT is a method that iscurrently developing rapidly. This method is very effective and efficient because it can result in close to experimental results and requiringa short time (Chandra, Asmuruf, \& Siallagan, 2020). Based on the above background, this study aims to determine the molecular structure model and the quantitative relationship of the activity structure (QSAR) of myristicin derivatives with the DFT method.

\section{METHODOLOGY}

\section{Biological Data}

The descriptor of biological activity and compounds studied in this research is the antioxidant activity of modified myristicin derivative compounds whose electron donor substitution groups consist of $-\mathrm{C}_{6} \mathrm{H}_{5},-\mathrm{NH}_{2},-\mathrm{Cl},-\mathrm{F}$, and $-\mathrm{H}$. The value of Half Maximal Inhibitory Concentration $\left(\mathrm{IC}_{50}\right)$ of antioxidants is known based on experimental research carried out (Wibowo et al., 2018).

\section{Modeling and Geometry Optimization of Myristicin Derivatives}

Myristicin derivative compounds are modeled in a simulation form based on 3D visualization. Their geometric shapes are optimized using the DFT (Density Functional Theory) method with the combined functional parameters of the three Becke and Lee-Yang-Parr (B3LYP) parameters. All calculations using the Bassist 6-31G set (Male, Wayan Sutapa, \& Merion Ranglalin, 2015). Optimization of molecular geometry is carried out to obtain a stable molecular structure (Janssens et al., 1990).

\section{Determination of Descriptors}

Determination of electronic descriptors is done using the DFT (Density Functional Theory) method.The computational calculations using the GaussView 6.016 and Marvin Sketch 64 programs in the form of dipole moment (MD), HOMO energy, LUMO energy, Gap energy $(\Delta \mathrm{EG})$, and atomic net charge $(\mathrm{qC} 1, \mathrm{qC} 2, \mathrm{qC} 3, \mathrm{qC} 4, \mathrm{qC} 5, \mathrm{qC} 6, \mathrm{qC} 8$, and, qC14). Calculations performed using QSAR, including Log P, Polar Surface Area (PSA), Polarizability, Harary Index, Randic Index, and Wiener Index, were analyzed using computational chemistry calculations (Velkov, 2009).

\section{Multilinear Regression Analysis}

Multilinear regression analysis was performed using the IBM SPSS 21 statistical program based on the Backward method to produce an equation model. Furthermore, the validation of the QSAR equation model was analyzed using data from the consideration of R, $\mathrm{R}^{2}$ and SE (Armunanto \& Sudiono, 2010). The accepted equation must have the following criteria: 1 ) The value of $R, R^{2}$ is close to 1 , and The SE value is small. A small SE indicates that the error rate between the data and the model is relatively small (Tahir, Wijaya, et al., 2010).

\section{RESULTS AND DISCUSSION}

\section{Optimization of Myristicin Derivative Compounds Molecular Geometry}

The molecular structure modeling of myristicin derivative compounds using the DFT method. Six different electron donor groups in the basicform of myristicin compounds (Figure 1). The compounds used in this study consist of five derivatives compounds and one of myristicin's basic structure. All the compounds had an $\mathrm{IC}_{50}$ tested experimentally (Table 1). An evaluation of the characteristics of the antioxidants present in the nutmeg plant examined by Jukic et al. showed that nutmeg essential oil has strong antioxidants (Agaus \& Agaus, 2019).

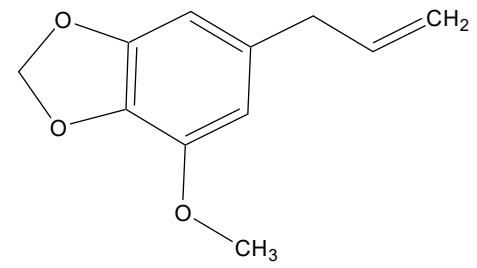

Figure 1.The basic Structure of 6-allyl-4methoxybenzo[d][1,3] dioxole $\left(\mathrm{M}_{0}\right)$ 
Table 1. Data Set of Five Myristicin Derivative Compounds

\begin{tabular}{ccc}
\hline $\begin{array}{c}\text { Compound } \\
\text { code }\end{array}$ & Donor substituent & $\log \mathrm{P}$ \\
\hline $\mathrm{M}_{1 .}$ & $\mathrm{C}_{6} \mathrm{H}_{5}$ & 3.97 \\
$\mathrm{M}_{2 .}$ & $\mathrm{NH}_{2}$ & 1.69 \\
$\mathrm{M}_{3}$. & $\mathrm{Cl}$ & 1.53 \\
$\mathrm{M}_{4 .}$ & $\mathrm{F}$ & 1.53 \\
$\mathrm{M}_{5}$ & $\mathrm{H}$ & 1.53 \\
\hline
\end{tabular}

In this study, the myristicin derivative compounds use an electron donor substitution group, namely $\mathrm{C}_{6} \mathrm{H}_{5},-\mathrm{NH}_{2},-\mathrm{Cl},-\mathrm{F},-\mathrm{H}$. The antioxidant test showed that the nutmeg had the highest component containing myristicin at $22.22 \%$, and the $\mathrm{IC}_{50}$ data was converted into $\log \mathrm{IC}_{50}$ is 1.34 . The actual properties (descriptors) of a compound can be predicted if the molecular structure is optimized to obtain a stable structure (Maahury, Male, \& Martoprawiro, 2020).
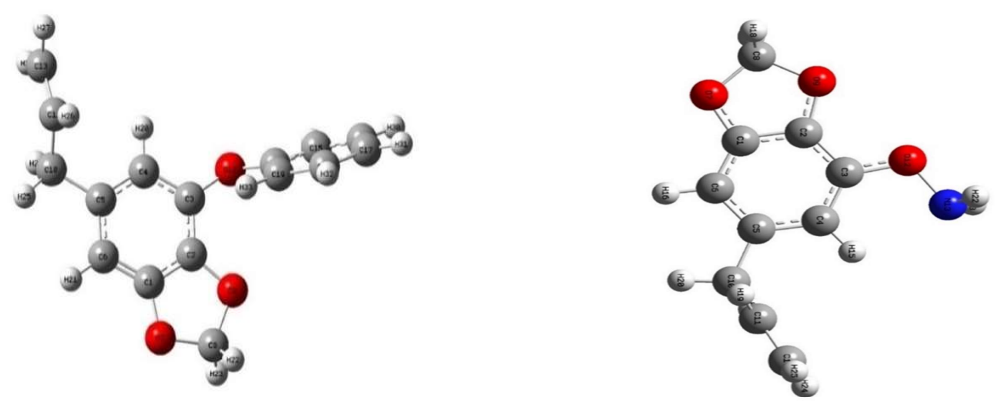

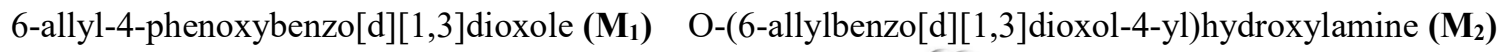
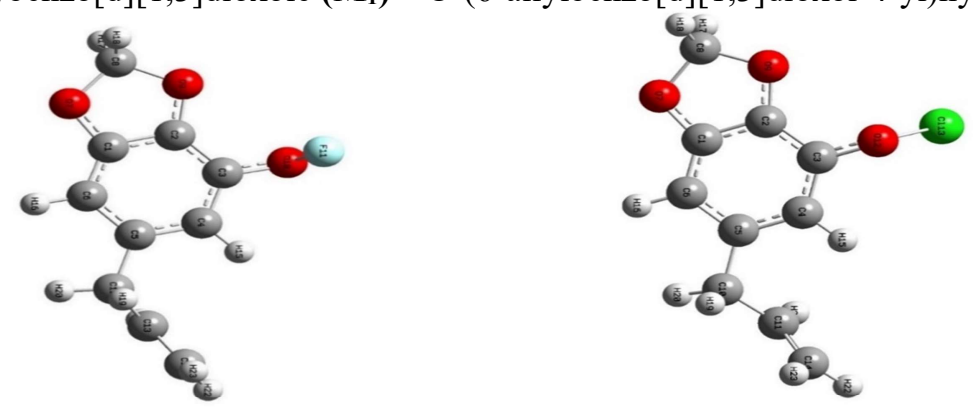

6-allylbenzo[d][1,3]dioxol-4-yl hypochlorite ( $\left.\mathbf{M}_{\mathbf{3}}\right)$ 6-allylbenzo[d][1,3]dioxol-4-yl hypofluorite $\left(\mathbf{M}_{4}\right)$

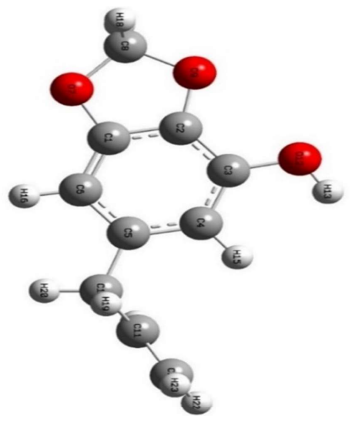

6-allylbenzo[d][1,3]dioxol-4-ol (M5)

Figure 2. The 3D structure based on the numberingfor compound $\mathrm{M}_{1}, \mathrm{M}_{2}, \mathrm{M}_{3}, \mathrm{M}_{4}, \mathrm{M}_{5}$ using DFT Method; M=Miristisin 
Tabel 2.Atomic Charge of Myristicin Derivative Compounds Using DFT Method

\begin{tabular}{ccccccc}
\hline $\begin{array}{c}\text { Atomic Charge } \\
(\mathrm{eV})\end{array}$ & $\mathrm{M}_{0}$ & $\mathrm{M}_{1}$ & $\mathrm{M}_{2}$ & $\mathrm{M}_{3}$ & $\mathrm{M}_{4}$ & $\mathrm{M}_{5}$ \\
\hline $\mathrm{qC}_{1}$ & 0.09 & 0.09 & 0.09 & 0.09 & 0.09 & -0.35 \\
$\mathrm{qC}_{2}$ & 0.11 & 0.11 & 0.11 & 0.11 & 0.11 & 0.15 \\
$\mathrm{qC}_{3}$ & 0.09 & 0.09 & 0.11 & 0.08 & 0.08 & -0.35 \\
$\mathrm{qC}_{4}$ & -0.02 & -0.02 & -0.02 & -0.02 & -0.02 & -0.07 \\
$\mathrm{qC}_{5}$ & -0.04 & -0.04 & -0.04 & -0.04 & -0.04 & -0.35 \\
$\mathrm{qC}_{6}$ & -0.02 & 0.06 & -0.02 & -0.02 & -0.02 & 0.15 \\
$\mathrm{qC}_{8}$ & 0.15 & 0.09 & 0.15 & 0.15 & 0.15 & -0.07 \\
$\mathrm{qC}_{14}$ & -0.07 & 0.06 & -0.07 & -0.07 & -0.07 & 0.15 \\
\hline
\end{tabular}

Table 3.Total Energy Data, Heat of Formation, Electronic Descriptors, Hydrophobic Descriptors and Steric Descriptors of Myristicin Derivatives

\begin{tabular}{ccccccccccccc}
\hline $\begin{array}{c}\text { Compound } \\
\text { code }\end{array}$ & $\begin{array}{c}\text { Total } \\
\text { Energy } \\
(\mathrm{kcal} / \mathrm{mol})\end{array}$ & $\begin{array}{c}\text { Heat of } \\
\text { Formation } \\
(\mathrm{kcal} / \mathrm{mol}- \\
\mathrm{kelvin})\end{array}$ & $\begin{array}{c}\text { HOMO } \\
\text { Energy } \\
(\mathrm{eV})\end{array}$ & $\begin{array}{c}\text { LUMO } \\
\text { Energy } \\
(\mathrm{eV})\end{array}$ & $\begin{array}{c}\Delta \mathrm{EG}(\mathrm{eV}) \\
\mathrm{M}\end{array}$ & $\begin{array}{c}\text { Dipole } \\
\text { Moment }(D)\end{array}$ & $\begin{array}{c}\text { Log } \\
\mathrm{P}\end{array}$ & $\begin{array}{c}\text { Polariz- } \\
\text { ability } \\
\left(\AA^{3}\right)\end{array}$ & $\begin{array}{c}\text { Polar } \\
\text { Surface } \\
\text { Area } \\
\left(\AA^{2}\right)\end{array}$ & $\begin{array}{c}\text { Indeks } \\
\text { Harary }\end{array}$ & $\begin{array}{c}\text { Indeks } \\
\text { Randic }\end{array}$ & $\begin{array}{c}\text { Indeks } \\
\text { Wiener }\end{array}$ \\
\hline $\mathrm{M}_{0}$ & 140.372 & 48.588 & -0.27799 & -0.15618 & 0.12181 & 1.6482113 & 1.34 & 21.62 & 27.69 & 39.21 & 11.58 & 292 \\
$\mathrm{M}_{1}$ & 175.49 & 61.811 & -0.28348 & -0.16958 & 0.1139 & 1.2891821 & 3.97 & 30.09 & 27.69 & 61.45 & 15.02 & 706 \\
$\mathrm{M}_{2}$ & 132.707 & 48.628 & -0.27678 & -0.15715 & 0.11963 & 1.6507633 & 1.69 & 21.32 & 53.71 & 39.21 & 11.29 & 292 \\
$\mathrm{M}_{3}$ & 115.701 & 47.18 & -0.28240 & -0.20193 & 0.08047 & 4.6800676 & 1.53 & 19.72 & 38.69 & 35.19 & 9.90 & 238 \\
$\mathrm{M}_{4}$ & 116.048 & 46.536 & -0.28663 & -0.20637 & 0.08026 & 4.4347508 & 1.53 & 19.72 & 38.69 & 35.19 & 9.90 & 238 \\
$\mathrm{M}_{5}$ & 121.377 & 43.962 & -0.28022 & -0.15718 & 0.12304 & 1.7627658 & 1.53 & 19.72 & 38.69 & 35.19 & 10.441 & 238 \\
\hline
\end{tabular}


Geometry optimization of the five myristicin derivative compounds was carried out to produce the best and stable structure. The molecular structure model of five myristicin derivative compounds is indicated by atomic number, atomic symbol, numbering, and charge. This is done to distinguish the atoms bound in the molecule. The results of modeling five myristicin derivative compounds can be seen in Figure 2.

The bonds between each atom in myristicin derivative molecules are caused by interaction between the valence electrons in each atom. This interaction will affect the strength of the bonds in the molecule. The factorsinfluencing the interactions between atoms in a molecule are electronegativity and electron affinity (Tahir, Wijaya, \& Bambang, 2003).

By using DFT (density functional theory), the optimization of the geometric structure of the five myristicin derivative compounds is determined through computational simulations. Compared with other myristicin derivative compounds, the M3 compound has the best structure, with total energy is $115.701(\mathrm{kcal} / \mathrm{mol})$, as shown in (Table 2). The total energy and heat of formation are the most important parameters in determining how much energy is needed in determining the most optimal structure with the smallest or close to zero energy (Ismiyarto et al., 2009).

\section{Quantitative Relationship Study of Activity Structure}

Through the quantitative relationship of activity structure (QSAR) study, the antioxidant biological activity of myristicin derivatives was determined by computational simulations. The study of the structure of antioxidant activity can be described quantitatively by calculating the structure of the compound under investigation. Descriptors were selected to produce myristicin derivative compounds' physical and chemical properties (Adhikari, Halder, Mondal, \& Jha, 2013).

Electronic descriptor calculations can be done using the DFT method. The computationally calculated electronic descriptor produces data in HOMO energy, LUMO energy, dipole moment (Table 3), and net atomic charge (Table 4). The dipole moment is related to the polarity of the myristicin derivative molecule, where the highest polarity is in the M3 compound, about 4.6800676 D. The orbitals for electronic excitation, involve the HOMO and LUMO. Electron excitation from HOMO to LUMO has a certain distance and requires energy, which can be measured from the energy difference between the HOMO and the LUMO.
Table 4.Results of Determination of the Equation Model

\begin{tabular}{ccc}
\hline $\begin{array}{c}\text { Compound } \\
\text { Code }\end{array}$ & $\log \mathrm{P}$ & $\log \mathrm{P}_{\text {predictions }}$ \\
\hline $\mathrm{M}_{1}$ & 3.97 & 0.5473343 \\
$\mathrm{M}_{2}$ & 1.69 & -1.4581628 \\
$\mathrm{M}_{3}$ & 1.53 & -1.6915776 \\
$\mathrm{M}_{4}$ & 1.53 & -1.7468346 \\
$\mathrm{M}_{5}$ & 1.53 & -2.3486929 \\
\hline
\end{tabular}

This energy is called the Gap Energy ( $\triangle \mathrm{EG})$, and the unit is eV. Gap energy is related to the stability and reactivity of the molecule, stability and reactivity can be seen through the energy difference (ŠpirtovićHalilović et al., 2014). produce data in the form of HOMO energy, LUMO energy, dipole moment. The less stable and more reactive Myristicin derivatives compound in this research is M4.The M4 has $\Delta \mathrm{EG}$ of about $0.08026 \mathrm{eV}$. This result is because the molecules with a small $\Delta \mathrm{EG}$ value are reactive and less stable. After all, they require less energy when an exciting electron from HOMO to LUMO.

Meanwhile, the derivative compound that more stable and less reactive is M5. M5 hasthe largest $\Delta \mathrm{EG}$, about $0.12304 \mathrm{eV}$. The compound has the highest $\Delta \mathrm{EG}$, the more stable and less reactive. This condition because it requires a large amount of energy to exciting electron from HOMO to LUMO. The electronic descriptors of the atomic charge are essential in determining the electronic interactions between atoms in molecules that are bonded to one another. This interaction will involve the electrons in the atom joining each other, thus affecting the charge value of each atom. The difference in charge values is influenced by the transfer of electrons to each atom attached to the molecule, the atomic charge can be seen in (Table 3).

The $\log \mathrm{P}$ value is related to the compound's polarity (water solubility), which indicates the distribution of antioxidant compounds in the human body after consumption. The good biological activity $\log \mathrm{P}$, is solubility in water and difficult to penetrate the lipid membrane at $0<\log \mathrm{P}<3$. Based on Table 2 , the lowest $\log \mathrm{P}$ is owned by the M3, M4, and M5 compounds, about 1.53 . The highest $\log \mathrm{P}$ is owned by the $\mathrm{M} 1$ compound, which is 3.97 . The difference in the Log P, shows how effective the polarity (solubility in water) of myristicin derivatives as an antioxidant drug after consumption. The polarizability or polarity of a compound is closely related to the number of electrons, and a large number of electrons affects the polarity.

The highest polarity value is represented by compound M1, amounting to $30.09 \AA$, where the more 
electrons, the easier the polarization. This result is consistent with the simulation of the calculation of the structure of the M1 compound, which is the molecule with the highest number of electrons among the other five myristicin derivative compounds. The higher the Polar Surface Area (PSA) value, the higher the polarity level, so that its solubility in body fluids is greater (Lee \& Park, 2011). When the Polar Surface Area (PSA) is greater, the greater the polarity and the easier it will dissolve in body fluids during the transport process to the cell membrane (Nindita, 2014). In (Table 2) it can be seen that the highest PSA value is found in M2 compound.

Harary index and Wiener index were chosen because the calculations are simple and therefore more acceptable. In addition, these three descriptors are commonly used in QSAR research. It can be seen from (Table 2) that the compound with the larger structure is M1 because the Harary index, Randic index and Wiener index are $61.45 ; 15.02 ; 706$. This condition occurs because molecules with large volumes will provide a greater topological index value. Several compounds have the same topological index value. This condition shows that the topological index descriptors are less sensitive to changes in the bond position of an atom. The more the same, the value of the descriptor indicates that the descriptor is less sensitive.

\section{Determination of the QSAR Equation Model}

When determining the QSAR equation model for myristicin-derived compounds, statistical analysis is required. The processed data is the follow-up data obtained from the optimization results using the DFT and QSAR methods. Then the statistical analysis is carried out. The study was carried out in two stages: correlation analysis and multiple linear regression analysis or multilinear regression analysis, to produce a QSAR equation model (Tahir, Mudasir, Yulistia, \& Mustofa, 2010). Correlation analysis was carried out to see relationship between biological activity and Log P.

The independent variables were 17 descriptors of myristicin derivative compounds M1-M5, including EHOMO, ELUMO, $\triangle \mathrm{EG}, \mathrm{MD}, \mathrm{qC} 1, \mathrm{qC} 2, \mathrm{qC} 3, \mathrm{qC} 4$, qC5, qC6, qC8, qC14, Polarizability, Polar Surface Area, Harary Index, Randic Index, Wiener Index. While the dependent variable is $\log P$. The correlation results show that all descriptors of myristicin derivative compounds have a relationship with biological activity as indicated by the value criteria that are close to the values +1 and -1 . Log $\mathrm{P}$ with $\log$ $P_{\text {Predictions }}$ obtained from the QSAR equation model can be seen in (Table 5 and Figure 3). This number shows that compounds with high activity are in compound M1, and compounds with low activity are in compound M5.

Table 5. QSAR Equation Model Using Multilinear Regression Method

\begin{tabular}{cccccc}
\hline Model & Descriptors & $\mathrm{n}$ & $\mathrm{R}$ & $\mathrm{R}^{2}$ & $\mathrm{SE}$ \\
\hline 1 & IW, qC8, & 6 & 1.000 & 0.926 & 0 \\
& HOMO, PSA, \\
& & & & \\
MD & & & & \\
\hline
\end{tabular}

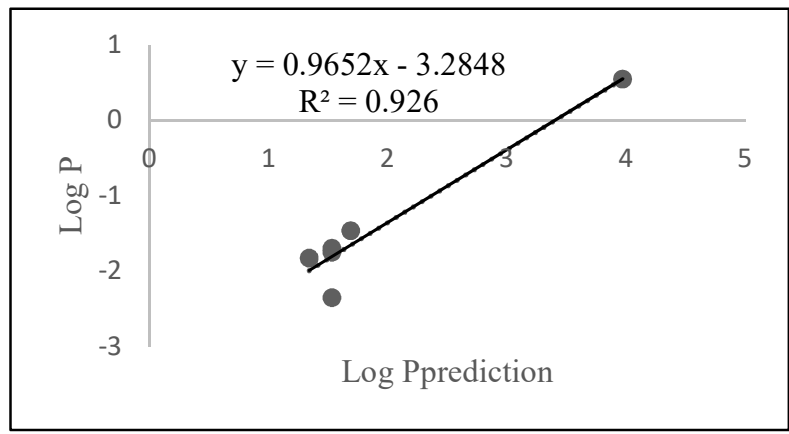

Figure 3. Correlation Curve Between Log P and Log

$$
P_{\text {Prediction }}
$$

The choice of the multilinear regression method is because it uses more than one independent variable data. There are 17 descriptors as independent variables. Then the descriptors were analyzed using the multilinear regression method. The data obtained through multilinear regression analysis was used to produce the QSAR model equation, where the values of $R, R^{2}$ and $S E$ were obtained from the analysis values of $\mathrm{R} 17$ descriptors for each of 5 myristicin derivatives. The criteria for selecting the best equation for the QSAR method is to pay attention to $\mathrm{R}$ and $\mathrm{R}^{2}$, which have a value greater than 0.5 for the accepted multilinear regression equation. This study's multilinear regression analysis results show that the best model is a model with five descriptors. There are the Wiener Index, qC8, HOMO Energy, Polar Surface Area, and Dipole Moment. Where the results of the statistical analysis of the equation model can be written the following equation:

$$
\begin{aligned}
\log \mathrm{P}= & -2,600+(0,006) \mathrm{IW}-(1,558) \mathrm{qC} 8- \\
& (6,532) \text { Еномо }+(0,014) \mathrm{PSA}+(0,113) \\
& \mathrm{MD}, \text { with } \mathrm{n}=6, \mathrm{R}=1,000, \mathrm{R}^{2}=0,926, \\
& \mathrm{SE}=0
\end{aligned}
$$

\section{CONCLUSION}

The DFT or density functional method of the molecular structure of the five myristicin derivatives 
has been modeled and optimized. The best QSAR equation model is obtained through multilinear regression analysis. This model can be used as an equation capable of predicting the biological activity of antioxidants in myristicin derivative compounds. The model obtained:

$$
\begin{aligned}
\log \mathrm{P}= & -2.600+(0,006) \mathrm{IW}-(1.558) \mathrm{qC} 8-(6.532) \\
& \text { EHOMO }+(0.014) \text { PSA }+(0.113) \mathrm{MD} \\
& \text { with } \mathrm{n}=6, \mathrm{R}=1.000, \mathrm{R}^{2}=0.926, \mathrm{SE}=0 .
\end{aligned}
$$

The QSAR equation model obtained by considering several parameters $\left(R, R^{2}\right.$, and $\left.S E\right)$ is the best.

\section{REFERENCES}

Adhikari, N., Halder, A. K., Mondal, C., \& Jha, T. (2013). Exploring Structural Requirements of Aurone Derivatives as Antimalarials by Validated Dft-Based Qsar, Hqsar, and Comfa-Comsia Approach. Medicinal Chemistry Research, 22(12), 6029-6045. https://doi.org/10.1007/ s00044-013-0590-8

Agaus, L. R., \& Agaus, R. V. (2019). Manfaat Kesehatan Tanaman Pala (Myristica fragrans) (Health Benefits of Nutmeg (Myristica fragrans )). MEDULA, 6(3), 662-665. https://doi.org/ 10.46496/medula.v6i3.9648

Armunanto, R., \& Sudiono, S. (2010). Relation of Electronic Structures with Their Antimalarial Activities on Artemisinin Derivatives. Indonesian Journal of Chemistry, 4(3), 212-217. https://doi.org/10.22146/ijc.21856

Ayunani, T. D., Hastuti, I. T., Ansory, H. M., \& Nilawati, A. (2018). Pemisahan Senyawa 1, 4terpineol dan Safrol dari Minyak Atsiri Biji Pala (Myristica Fragrans Houtt) dan Uji Aktivitas Antibakteri Terhadap Shigella dysenteriae. Jurnal Farmasi Indonesia, 15(1), 88-100.

Chandra, C., Asmuruf, F., \& Siallagan, J. (2020). Kajian Reaktivitas Stabilitas Struktur Senyawa Miristin Dan Turunannya Dengan Menggunakan Metode Fungsional Kerapatan. JURNAL AVOGADRO, 4(1), 24-30. https://doi.org/ 10.31957/.v4i1.1169

Damayanti, R., \& Ervilita, R. (2017). Potensi Minyak Atsiri Daun Pala Sebagai Antioksidan. Seminar Nasional II USM 2017, 1, 554-556.

Dungir, S. G., Katja, D. G., \& Kamu, V. S. (2012). Aktivitas Antioksidan Ekstrak Fenolik dari Kulit Buah Manggis (Garcinia mangostana L.). Jurnal MIPA, 1(1), 11-15. https://doi.org/10.35799/ jm.1.1.2012.424
Fadillah, A., Rahmadani, A., \& Rijai, L. (2017). Analisis Kadar Total Flavonoid dan Uji Aktivitas Antioksidan Ekstrak Daun Kelubut (Passiflora foetida L.). Proceeding of Mulawarman Pharmaceuticals Conferences, 5, 21-28. https://doi.org/10.25026/mpc.v5i1.217

Fadiyah, I., Lestari, I., \& Mahardika, R. G. (2020). Antioxidant Capacity of Rukam Fruit Extract (Flacourtia rukam) Using Microwave Assisted Extraction (Mae) Method. Indonesian Journal of Chemical Research, 7(2), 107-113. https://doi.org/10.30598//ijcr.2020.7-ina

Ginting, B., Mustanir, M., Helwati, H., Desiyana, L. S., Eralisa, E., \& Mujahid, R. (2017). Antioxidant Activity of N-Hexane Extract of Nutmeg Plants from South Aceh Province. Jurnal Natural, 17(1), 39-44. https://doi.org/10.24815/jn.v17i1.6969

Hasanan, N. (2015). Aktivitas Antioksidan Ekstrak Etanol Daun Salam. Pena Medika Jurnal Kesehatan, 5(1), 55-59. https://doi.org/ 10.31941/pmjk.v5i1.345

Ismiyarto, I., Ngadiwiyana, N., \& Mustika, R. (2009). Isolasi, Identifikasi Minyak Atsiri Fuli Pala (Myristica fragrans) dan Uji Aktivitas Sebagai Larvasida. Jurnal Kimia Sains dan Aplikasi, 12(1), 23-30. https://doi.org/10.14710/ jksa.12.1.23-30

Isnaeni, L., Kasmui, K., \& Kusuma, S. B. W. (2016). Kajian Hubungan Kuantitatif Struktur Dan Aktivitas Antioksidan Senyawa Analog Kalkon. Indonesian Journal of Chemical Science, 5(2), 119-123.

https://doi.org/10.15294/ijcs.v5i2.11430

Janssens, J., Laekeman, G. M., Pieters, L. A. C., Totte, J., Herman, A. G., \& Vlietinck, A. J. (1990). Nutmeg oil: Identification and quantitation of its most active constituents as inhibitors of platelet aggregation. Journal of Ethnopharmacology, 29(2), 179-188. https://doi.org/10.1016/03788741(90)90054-W

Kilo, A. L., Aman, L. O., Sabihi, I., \& Kilo, J. L. (2019). Studi Potensi Pirazolin Tersubstitusi 1-N dari Thiosemicarbazone sebagai Agen Antiamuba melalui Uji In Silico. Indonesian Journal of Chemical Research, 7(1), 9-24. https://doi.org/ 10.30598//ijcr.2019.7-akr

Lee, J. Y., \& Park, W. (2011). Anti-Inflammatory Effect of Myristicin on RAW 264.7 Macrophages Stimulated with Polyinosinic-Polycytidylic Acid. Molecules, 16(8), 7132-7142. https://doi.org/ 10.3390/molecules 16087132

Maahury, M. F., Male, Y. T., \& Martoprawiro, M. A. (2020). DFT Study of Leuco-Indigo and Indigo as 
Active Material in Dye-Sensitized Solar Cell. Molekul, 15(2), 114-120. https://doi.org/ 10.20884/1.jm.2020.15.2.592

Male, Y. T., Wayan Sutapa, I., \& Merion Ranglalin, O. (2015). Computational Study Natural Color Essence (Dyes) As Active Material on Organic Solar Cell With Density Functional Theory (DFT). J. Chem. Res, 2, 205-212.

Nindita, L. D. (2014). Modeling Hubungan Kuantitatif Struktur Dan Aktivitas (HKSA) Pinocembrin Dan Turunannya Sebagai Anti Kankermodelling a Quantitative Structure and Activity Relationship (qsar) in Pinocembrin and Its Derivative as the Anti-Cancer. Unesa Journal of Chemistry, 3(2), 26-34.

Rifai, A. A., Kasmui, K., \& Hadisaputro, S. (2014). Kajian HKSA Senyawa Turunan Deoksibenzoin Terhadap Aktivitas Antioksidan Menggunakan Analisis Regresi Multilinear. Indonesian Journal of Chemical Science, 3(3), 222-226. https://doi.org/10.15294/ijcs.v3i3.4113

Rohmatussolihat, R. (2015). Antioksidan, Penyelamat Sel-sel Tubuh Manusia. Biotrends, 4(1), 5-9.

Souhoka, F. A., Hattu, N., \& Huliselan, M. (2019). Antioxidant Activity Test of Methanol Extract of Kesumba Keling. Indonesian Journal of Chemical Research, 7(1), 25-31.

Špirtović-Halilović, S., Salihović, M., Veljović, N., Osmanović, A., Trifunović, S., \& Završnik, D. (2014). Chemical reactivity and stability predictions of some coumarins by means of DFT calculations. Bulletin of the Chemists and Technologists of Bosnia and Herzegovina, 43, 5760.
Tahir, I., Mudasir, M., Yulistia, I., \& Mustofa, M. (2010). Quantitative Structure-Activity Relationship Analysis (qsar) of Vincadifformine Analogues as the Antiplasmodial Compounds of the Chloroquinosensible Strain. Indonesian Journal of Chemistry, 5(3), 255-260. https://doi.org/10.22146/ijc.21800

Tahir, I., Wijaya, K., \& Bambang, P. (2003). Terapan Analisis Hansch Untuk Aktivitas Antioksidan Senyawa Turunan Flavon / Flavonol. Seminar Khemometri, 1-9.

Tahir, I., Wijaya, K., Purwono, B., \& Widianingsih, D. (2010). QSAR Study of Flavone / Flavonol Analogues as the Antiradical Compounds Based on Hansch Analysis. Indonesian Journal of Chemistry, 3(1), 48-54. https://doi.org/10.22146/ ijc. 21905

Velkov, Z. (2009). Quantum-chemical Approach to the Modeling of Antioxidant Activity (Theoretical descriptors of antioxidants). Scientific Research Journal of South-West University, 2(1), 41-45.

Wibowo, D. P., Febriana, Y., Riasari, H., \& Auilifa, D. L. (2018). Essential Oil Composition, Antioxidant and Antibacterial Activities of Nutmeg (Myristica fragrans Houtt) from Garut West Java. Indonesian Journal of Pharmaceutical Science and Technology, 5(3), 82-87. https://doi.org/10.24198 /ijpst.v5i3.16030

Widyastuti, W., Kusuma, A. E., Nurlaili, N., \& Sukmawati, F. (2016). Aktivitas Antioksidan dan Tabir Surya Ekstrak Etanol Daun Stroberi (Fragaria x ananassa A.N. Duchesne). Jurnal Sains Farmasi \& Klinis, 3(1), 19-24. https://doi.org/10.29208/jsfk.2016.3.1.92 